\title{
Sheep wool-derived hydrolyzed keratin from tannery waste of the tanning industry using perhydrol
}

\author{
Prayitno*, Dona Rahmawati, Gresy Griyanitasari \\ Center for Leather, Rubber, and Plastics. Jl. Sokonandi No. 9 Yogyakarta 55166, Indonesia \\ *Corresponding author. Tel.:+62 274 512929, 563939; Fax.:+62 274563655 \\ E-mail: prayitno_bbkkp@yahoo.com
}

Received: 06 September 2017 Revised: 25 September 2017 Accepted: 16 October 2017

\begin{abstract}
Sheep wool waste discharged from leather tanning industry recently has posed a problem in relation to its treatment because of its sizeable quantity and its difficulty to degrade. Wool is composed mainly of keratin. It is a protein with a high content of disulfide bonds which cause the protein keratin cannot dissolve in water and resist of diluted acids and alkalis. Keratin can be hydrolyzed to produce keratin hydrolysates which have many benefits such as for cosmetic additives. Research into the use of waste wool of sheep originated from the sheep leather tanning industry had been performed by using a hydrolyzed system to produce protein keratin. The waste wool used came from unhairing by painting and conventional unhairing. Hydrolysis was done using hydrogen peroxide $50 \%$ amounting to $70 \mathrm{ml}$ for every $40 \mathrm{gr}$ of wool. Hydrogen peroxide was added to wool immersed in the $0.5 \mathrm{M} \mathrm{NaOH}$ solution for three hours. The length of hydrolysis ranged from 4, 5, to 6 hours and the mix was stirred shortly every 1 hour followed by filtration using a coarse sieve. To precipitate the hydrolyzed keratin, the $\mathrm{pH}$ was decreased to 4-5 using the $2 \mathrm{M} \mathrm{HCl}$ solution and after separation of the precipitation, it was dried in the oven at a temperature not more than $50{ }^{\circ} \mathrm{C}$ for 2 days. The research findings showed that a maximum of $69.19 \%$ of keratin hydrolysates was generated using the raw material of waste wool through a conventional process with a total of hydrolysis time by 6 hours, whereas the maximum protein generated was $66.99 \%$ using waste wool through a conventional process with a total of hydrolysis time by 4 hours. The FTIR test showed the presence of groups of amides, cysteic acids, and cystine-S-monoxide.
\end{abstract}

Keywords: Hydrolyzed keratin, hydrogen peroxide, unhairing by painting, conventional unhairing, waste wool.

\section{INTRODUCTION}

The waste wool which resulted from the tanning process reaches $20-30 \%$ by weight against the skin resulted. This raise problems in relation to the treatment of this waste, because waste wool cannot be degraded immediately by microorganisms. Currently, waste wool is controlled using the landfill system. Some problems arise because the difficulty in degradation causes problems to soil fertility and other soil functions. According to Bayramoglu et al. (2014), wool is essentially an epidermis structure that forms the outer coverings of the main structures of the body in the form of the protein keratin, it is a protein fibrous which is rich content of sulfur. Protein keratin is a type of structural proteins that are chemically nonreactive, have strong mechanical properties, and are insoluble in water and organic compounds.
It is chemically characterized by a cysteine content in the sequence of keratin amino (Gupta et al., 2012). According to Cardamone (2010), wool contains $95 \% \mathrm{w} / \mathrm{w}$ pure keratin and keratin derived from wool is clay, hard, and insoluble. According to Sarkar (1995), the amount of keratin in the skin varies according to species and age of the animal. Keratin is classified into two types, those are $\alpha$-keratin and $\beta$-keratin. The $\alpha$-keratin is mainly the keratin in the hair and weaves, whereas the $\beta$-keratin is the keratin mostly found in nails, horns, reptile claws, and bird beak (Kannahi \& Ancy, 2012). Whereas Bragulla \& Homberger (2009) classifies keratin into two types according to their isoelectric point ( $\mathrm{pI}$ ), namely keratin type I (acidic) and keratin type II (basic). Bovine keratin type I has a $\mathrm{pI}<5.6$, while keratin type II has a $\mathrm{pI}>6.0$. Keratin is fibrous which can be 
isolated from the wool into a protein hydrolysate used for a variety of additives in some types of cosmetics. Studies have been performed to extract keratin from several sources of raw materials. Villa et al. (2013) extracted keratin from chicken feathers using enzyme-producing microbial keratinase Bacillus subtilis $s p$ whereas Kannahi \& Ancy (2012) extracted keratin from chicken feathers using enzymes produced by Aspergillus flavus $s p$ and can hydrolyze protein keratinase until 9095\%. Mokrejs et al. (2011) state that keratin hydrolysates can be extracted using proteolytic enzymes. The principle for extracting keratin is to breakdown the sulfur bonds in cysteine into a hydrolysate which can easily dissolve protein. A previous experiment has been done by Bayramoglu et al. (2014) to hydrolyze wool keratin for creating skin emulsion using hydrogen peroxide with the following conditions: hydrolysis time lasted for 5 (five) hours and keratin was precipitated by $0.5 \mathrm{M} \mathrm{HCl}$ solution. To improve the resulting keratin and to get a greener process, research into extraction of keratin using hydrogen peroxide needs to be performed to find out the optimum hydrolysis time and reduce the volume of the $\mathrm{HCl}$ solution used.

\section{MATERIALS AND METHODS Materials}

The raw material used in this research was wool obtained from sheepskin tannery waste using conventional unhairing and unhairing by painting in beamhouse operations. Chemicals used to process were $\mathrm{Na}_{2} \mathrm{CO}_{3}$, wetting agents, $\mathrm{NaOH}, \mathrm{HCl}, \mathrm{pH}$ sticks, $\mathrm{Na}_{2} \mathrm{~S}, \mathrm{Ca}(\mathrm{OH})_{2}, \mathrm{NH}_{4} \mathrm{Cl}$, degreasing agents, and $\mathrm{H}_{2} \mathrm{O}_{2} 50 \%$ solution. The equipment to hydrolyze keratin consisted of an oven, glass apparatus, a thermometer, a $\mathrm{pH}$ meter and testing equipments such as Kjeldahl apparatus and fourier transform infra red (FTIR) IR Prestige21 Shimadzu.

\section{Methods \\ Research design}

This experiment was arranged in a randomized complete factorial design, which consisted of two variables of the material used in accordance with the method of the unhairing process and three variables in hydrolysis times. Each treatment was repeated three times so that there were a total of 18 experiments. Each experiment was analyzed in terms of the weight of the keratin generated in presentation of the raw material used, total protein, and structure of protein with FTIR.

\section{Keratin extraction method}

The method used in this research was based on the experiment conducted by Bayramoglu et al. (2014). Waste wool was washed with water to remove $\mathrm{Na}_{2} \mathrm{~S}$ and $\mathrm{Ca}(\mathrm{OH})_{2}$, then it was dried under the sunlight. 40 grams of waste wool were soaked in 1 liter of the $0.5 \mathrm{M} \mathrm{NaOH}$ solution for 3 hours. $80 \mathrm{ml}$ of $\mathrm{H}_{2} \mathrm{O}_{2}$ was added each time, it was stirred until 4, 5, and 6 hours. Next, it was filtered using a coarse strainer and the $2 \mathrm{M} \mathrm{HCl}$ solution was added until its $\mathrm{pH}$ was equal to 4 to 4.5 to allow precipitation of keratin. The keratin was dried in the oven at a temperature of $45^{\circ} \mathrm{C}$ for 2 days and processed in such a way that it changed into powder.

\section{Testing}

Testing was done to determine total protein content and weight of keratin generated and also the total protein content and the chemical structure of protein keratin.

\section{Data analysis}

The weight of keratin and the total protein content obtained from the experiment were analyzed statistically using the method analysis of variance using SPSS for each treatment continued with the LSD analysis with a $95 \%$ degree of significance.

\section{RESULTS AND DISCUSSION}

The weight of keratin and the total weight of the protein content generated in the experiment using waste wool from conventional unhairing and using waste wool from unhairing by painting are presented in Figure 1.

\section{Protein contents}

To determine the influence of the treatment on the keratin hydrolysate produced, a statistical analysis, i.e. the analysis of variance was undertaken as presented in Tables 1 and 2. Results of the analysis of variance as listed in Table 1 show that there are significant differences viewed from the factor of raw materials in the weight of the protein content between the keratin hydrolysates generated from waste wool processed using the conventional method and the keratin hydrolysates generated by the painting process $\left(\mathrm{t}_{\text {table }}=48.05>\mathrm{t}_{\text {count }}=\right.$ 4.96 ), which mean that the raw material greatly 

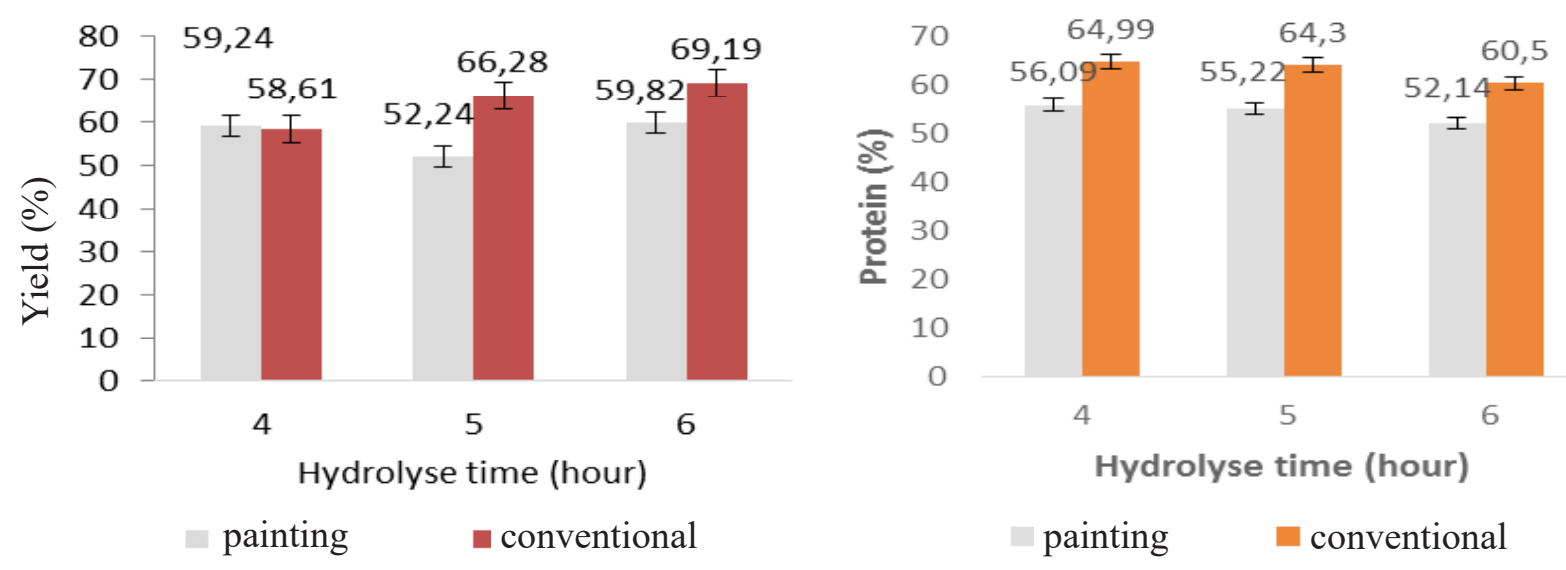

Figure 1. Percentages of the weight and the total protein keratin generated.

influences the protein content of the resulting hydrolyzed keratin. Waste wool processed using a conventional method generated hydrolyzed keratin with a protein content by $63.26 \%$ whereas that produced by the painting process had a protein content by $54.47 \%$. According to Cardamone (2010), wool contains up to $95 \%$ by weight of pure keratin. The lower keratin content generated in this experiment may be caused by the age and species of the sheep (Sarkar, 1995).

It is likely because the time of wool exposure to basic liquor is much more longer for wool processed using the conventional unhairing method than that processed using the painting method so that the wool processed conventionally became more swollen, which in turn caused keratin to be more easily hydrolyzed by hydrogen peroxide. As for the time factor, according to results of the statistical analysis of the hydrolyzed keratin using ANOVA, there was a significant difference $\left(t_{\text {count }}\right.$ $\left.=4.15>\mathrm{t}_{\text {table }}=4.10\right)$, but the LSD calculation at a $5 \%$ degree of significance performed afterwards suggested no significant differences.

\section{Yield (Percentage of keratin hydrolysate against the raw material weight)}

Results of the ANOVA of the protein keratin extracted are listed in Table 2. The weight percentages of the hydrolyzed keratin which was generated with the raw material of waste wool produced either using a conventional process or with a painting process did not indicate significant differences $\left(\mathrm{t}_{\text {count }}=3.77<\mathrm{t}_{\text {table }}=4.96\right)$. It means that the hydrolysis time lasting for 4.5 and 6 hours did not generate different results for the protein keratin extracted $\left(\mathrm{t}_{\text {count }}=2.40<\mathrm{t}_{\text {table }}=4.10\right)$. This is possibly because the protein content present in keratin of the wool has been extracted completely.

The resulting $\mathrm{pH}$ of the hydrolyzed keratin accorded with the $\mathrm{pH}$ range for settling of

Table 2. Analysis of variance (ANOVA) for the protein content.

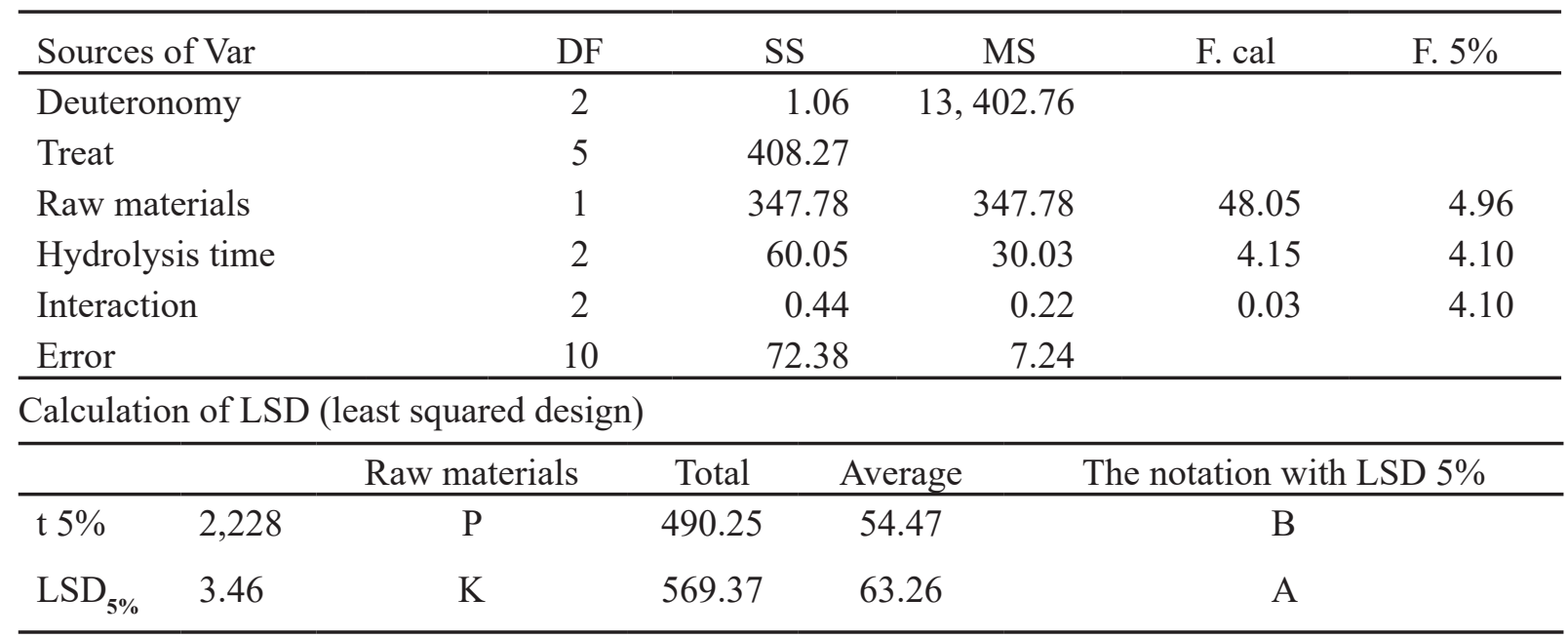


Table 3. Analysis of variance (ANOVA) of the protein keratin extracted.

\begin{tabular}{lccccc}
\hline Sources of Var & DF & SS & MS & F. cal & F. 5\% \\
\hline Deuteronomy & 2 & 106.16 & 53.08 & & \\
Treat & 5 & 676.76 & & & \\
Raw materials & 1 & 158.06 & 158.06 & 3.77 & 4.96 \\
Hydrolysis Time & 2 & 201.68 & 100.84 & 2.40 & 4.10 \\
Interaction & 2 & 317.01 & 158.50 & 3.78 & 4.10 \\
Error & 10 & 419.43 & 41.94 & & \\
\hline
\end{tabular}

protein keratin, which ranged from 4 to 5 . This is consistent with the $\mathrm{pH}$ of the electrostatic protein containing hydrolyzed keratin. The keratin of sheep falls into the category of keratin type K25 which has an isoelectric pH of 4.7 (Bragulla \& Homberger, 2009).

\section{FTIR Test}

The structure of hydrolyzed keratin analyzed using FTIR indicated that the spectrum of the hydrolyzed keratin generated by Bayramoglu et al. (2014) and the hydrolyzed protein generated by the research into keratin extraction as presented in Figures 2 and 3 had similar spectra. The FTIR spectrum of the test zone ranging from 1,400 to $4,000 \mathrm{~cm}^{-1}$ is known as the "function group" zone. The peak spectra of the "function group" zone for keratin hydrolysates was at wavelengths of 3274 ,

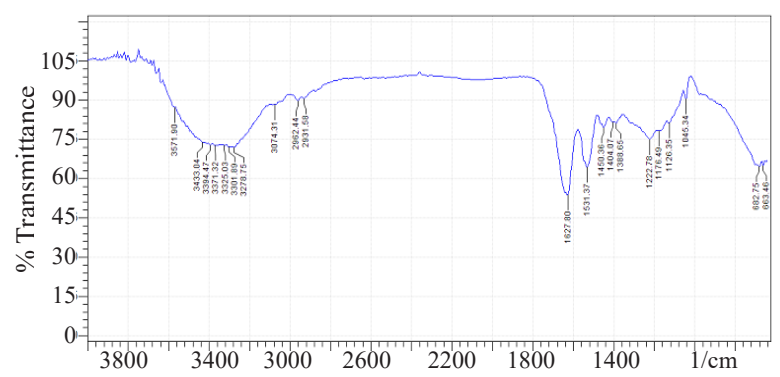

Figure 2. FTIR spectra of keratin resulting from the painting process.

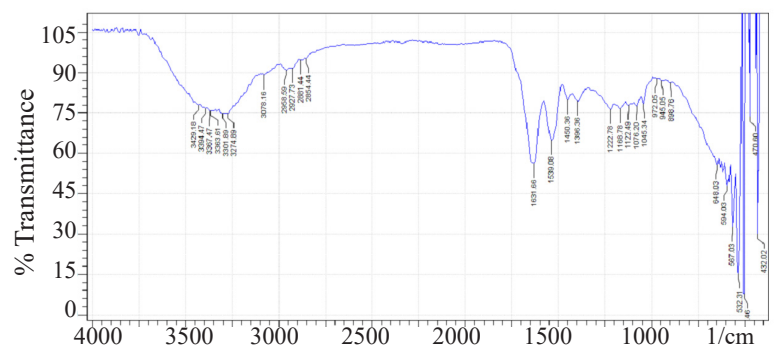

Figure 3. FTIR spectra of keratin resulting from the conventional process.
2962,1539 , and $1450 \mathrm{~cm}^{-1}$ whereas the FTIR spectra of Bayramoglu et al. (2014) absorbs ion peak to hydrolyze keratin was found at wavelengths of $3279,2962,1536$, and $1449 \mathrm{~cm}^{-1}$

Research by Bayramoglu et al. (2014) resulted hydrolyzed keratin generate peak at wavelengths of $1680-1645 \mathrm{~cm}^{-1}$ for the amide II, 1550 $1515 \mathrm{~cm}^{-1}$ for the amide II, and for the amide III in $1435 \mathrm{~cm}^{-1}$ cystein-S-sulfonate (Cy-S-S)-3) at 1012 $\mathrm{cm}^{-1}$, cysteic acid $\left(\mathrm{Cy}-\mathrm{SO}_{3} \mathrm{H}\right)$ at $1045 \mathrm{~cm}^{-1}$ cystine--S-monoxide (Cy-SO-S-Cy) on $1080 \mathrm{~cm}^{-1}$, cystine-S-dioxide (CySO $-\mathrm{S}-\mathrm{Cy}$ ) in $1137 \mathrm{~cm}^{-1}$. The FTIR test of hydrolyzed keratin from this research showed that the zone of amide obtained at peak amide I was in $1634.81 \mathrm{~cm}^{-1}$, peak amide II was in $1535.29 \mathrm{~cm}^{-1}$, amide III was in 1448.01 $\mathrm{cm}^{-1}$, cysteic acid was in $1045.02 \mathrm{~cm}^{-1}$, and cystine-S-monoxida was in $1081.10 \mathrm{~cm}^{-1}$. According to Bayramoglu et al. (2014), amide I with a peak in $1650 \mathrm{~cm}^{-1}$ and amide II with a peak in 1547 $\mathrm{cm}^{-1}$ have a helix-shaped structure.

\section{CONCLUSIONS}

Based on the research findings, it can be concluded that keratin hydrolysates can be generated from extraction of waste wool through hydrolysis using hydrogen peroxide with hydrolysis time lasting for 4, 5, and 6 hours. The percentages of the protein keratin resulting from waste wool originated from conventional processes were 64.99, 64.30 , and $60.50 \%$ respectively, while the percentages of the protein keratin resulting from waste wool originated from the painting process were $56.09,55.22$, and $52.14 \%$ respectively. The percentages of the hydrolyzed keratin resulting from the extraction using waste wool as the raw material were $58.61,66.28$, and $69.19 \%$, respectively for the conventional process and were 59.24, 52.24 , and $59.82 \%$, respectively for painting process. The FTIR test results showed the presence of results of cluster-cluster amide, cysteic acid, 
and cystine-S-monoxide in the hydrolyzed keratin generated.

\section{ACKNOWLEDGEMENT}

The authors thank to the Center for Leather, Rubber and Plastics for the facilities and funding in this study.

\section{REFERENCES}

Bayramoglu, E., Yorgancioglu, A., Yeldiyar, G., \& Onem, E. (2014). Extraction of keratin from unhairing wastes of goat skin and creating new emulsion formulation containing keratin and calendula flower (Calendula officinalis L.). Journal American Leather Chemists Association, 109(2), 49-55.

Bragulla, H. H., \& Homberger, D. G. (2009). Structure and functions of keratin proteins in simple, stratified, cornified and keratinized epithelia. Journal of Anatomy 214, (4), 516-559.

Cardamone, J. M. (2010). Investigating the microstructure of keratin extracted from wool: Peptide sequence (MALDI-TOF/TOF) and protein conformation (FTIR). Journal of Molecular Structure, 969(1-3), 97-105.

https://doi.org/10.1016/j.molstruc.2010.01.048
Gupta, A., Kamarudin, N. B., Kee, C. Y. G., \& Yunus, R. B. M. (2012). Extraction of protein from chicken feather keratin. Journal of Chemistry and Chemical Engineering, 6(8), 732.

Kannahi. M. \& Ancy. R. J. (2012) Keratin degradation and enzyme producing ability of Aspergillus flavus and Fusarium solani from soil. Journal of Chemical and Pharmacentical Research, 4(6), 3245-3248.

Mokrejs, P., Krejci, O., \& Svoboda, P. (2011). Producing keratin hydrolysates from sheep wool. Oriental Journal of Chemistry, 27(4), 1303-1309.

Sarkar, K.T. (1995). Theory and practice of leather manufacture (Revised edition). Madras, India: The C.L.S. Press.

Villa, A. L. V., Aragão, M. R. S., dos Santos, E. P., Mazotto, A. M., Zingali, R. B., de Souza, E. P., \& Vermelho, A. B. (2013). Feather keratin hydrolysates obtained from microbial keratinases: effect on hair fiber. BMC Biotechnology, 13(1), 1. https://doi.org/10.1186/1472-6750-13-15 
